\title{
Pengaruh Gangguan Tidur Terhadap Kadar Hormon Testosteron dan Jumlah Spermatozoa pada Tikus Jantan Wistar
}

\author{
Leni Tri Wahyuni ${ }^{1}$, Adnil Edwin Nurdin² ${ }^{2}$ Eliza Anas $^{3}$
}

\begin{abstract}
Abstrak
Tingginya angka infertilitas pada pria disebabkan antara lain oleh kualitas produksi spermatozoa dan gangguan hormonal. Tujuan penelitian ini adalah untuk mengetahui pengaruh gangguan tidur terhadap kadar hormon testosteron dan jumlah spermatozoa. Jenis penelitian adalah eksperimen laboratorium dengan desain post test only control group design. Populasi tikus jantan Wistar berumur 2-3 bulan, dan berat badan $300-350$ gr. Sampel sebanyak 24 ekor dibagi atas 4 kelompok yaitu: 1 kelompok kontrol dan 3 kelompok perlakuan. Variabel independen adalah gangguan tidur dan variabel dependen adalah kadar hormon testosteron dan jumlah spermatozoa. Analisa data mengunakan metode ANOVA dan dilanjutkan dengan uji statistik Multiple Comparisons jenis Bonferroni. Hasil penelitian menunjukkan ada perbedaan bermakna rerata kadar hormon testosteron kelompok kontrol dan perlakuan dengan nilai $p=0,000$. Gangguan tidur memberikan perbedaan bermakna terhadap kadar hormon testosteron. Terdapat perbedaan bermakna rerata jumlah spermatozoa kelompok kontrol dengan perlakuan dengan nilai $p=0.000$. Gangguan tidur juga memberikan perbedaan bermakna terhadap jumlah spermatozoa. Kesimpulan penelitian ini ialah terdapat pengaruh yang bermakna antara gangguan tidur terhadap kadar hormon testosteron dan jumlah spermatozoa pada tikus jantan wistar.
\end{abstract}

Kata kunci: gangguan tidur, hormon testosteron, jumlah spermatozoa

\section{Abstract}

The increasing of infertility is caused by the quality of sperm production and hormonal disturbance. The objective of this study was to find out the effect of sleeping disturbance to the quality of testosterone hormone and the number of sperm. This was a laboratory experimental research with post-test only control group design. The populations were 2-3 months, 300-350 grams of weight, male rats. The sample was 24 rats which consisted of 4 groups: one control group and three experimental groups. Sleeping disturbance was an independent variable, while the quality of sperm testosterone hormone and the number of sperm were dependent variables. The data of the research were analyzed statistically by ANOVA method and Bonferroni multiple comparison. There was a significant different of the mean of testosterone hormone quality between control group and experimental group with $p=0,000$. Sleeping disturbance gave significant different to the quality of testosterone hormone. There was a significant different on the number of sperm quality between control group and experimental group with $p=0,000$. Sleeping disturbance gave significant different to the number of sperm quality. The conclusion from this study is that there is effect of sleeping disturbance to testosterone hormone quality and the number of sperm on the wistar male rats.

Keywords: sleeping disturbance, testosterone hormone, the number of sperm

Affiliasi penulis : Program Studi Magister S2 Biomedik FK UNAND (Fakultas Kedokteran Universitas Andalas Padang), 2. Bagian Psikiatri FK UNAND/RSUP Dr. M. Djamil Padang, 3. Bagian Biologi FK UNAND
Korespondensi : Leni Tri Wahyuni, E-mail:

lenitriwahyuni@yahoo.com, Telp: 08126740889 


\section{PENDAHULUAN}

Perubahan globalisasi ternyata memberikan efek pada infertilitas selama 20 tahun terakhir. Pada tahun 2010 hampir 50 juta pasangan diseluruh dunia tidak dapat hamil setelah lima tahun menikah. ${ }^{1}$ Infertilitas didefinisikan sebagai hilangnya kemampuan pasangan untuk hamil dan melahirkan anak. Pasangan diduga mengalami infertilitas jika tidak terjadi kehamilan setelah berhubungan seksual tanpa menggunakan kontrasepsi secara teratur dalam waktu satu tahun. ${ }^{2}$ Ada dua faktor yang mempengaruhi kesehatan reproduksi yaitu faktor endogen meliputi tahap intra seluler, seluler jaringan, organobiologik dan faktor luar meliputi lingkungan, pola hidup dan gaya hidup. ${ }^{3}$

Penyebab terjadinya infertilitas sangat bervariasi. Pada pria infertil sering ditemukan kualitas sperma yang tidak baik, kadang-kadang produksi spermatozoa dalam testis yang sedikit dan testis sendiri yang terlalu kecil, serta sebab lain yang menyebabkan mutu sperma berkurang akibat dari epididimitis, prostatitis, varikokel atau kelainan endokrin. ${ }^{4}$

Menurut ahli andrologi, faktor penyebab kejadian infertilitas ini tidak terlepas dari produksi spermatozoa dan gangguan hormonal seperti hormon testosteron. Penyebab lain dari infertilitas adalah faktor umur, frekuensi hubungan seksual, lingkungan, gizi, perubahan social dan gaya hidup yang tidak sehat seperti kualitas tidur yang kurang, stres dan depresi, merokok dan mengkonsumsi alkohol. ${ }^{5}$

Salah satu faktor resiko terjadinya infertilitas adalah kurang kualitas tidur atau gangguan tidur akibat tuntutan gaya hidup. Gangguan tidur dapat terjadi akibat stres yang bisa menyebabkan gangguan neurobiologik, dimana gangguan tidur akan memicu peningkatan aktivitas sumbu hypothalamic-pituitariadrenal (HPA). ${ }^{6}$ Akibat peningkatan sumbu HPA, sehingga merangsang korteks adrenal untuk mengeluarkan kortisol. Kotisol merupakan hormon kortikosteroid yang mencakup glukokortikoid. Tingginya konsentrasi glukokortikoid di darah akan mempengaruhi hipotalamus dan hipofisis, akibatnya mengganggu sekresi gonadotropin-releasing hormone $(\mathrm{GnRH})$ dan mengurangi kosentrasi plasma Luteinizing Hormone (LH). ${ }^{7}$
Venancio et al pada tahun 2012 dalam penelitiannya mengemukakan bahwa kurang tidur akan memicu kelainan hormonal, karena menyebabkan sindrom metabolik, yang dapat merubah seks pria, yang mana kurang tidur menunjukan pengurangan kadar testosteron, yang disebabkan oleh stres sehingga mempengaruhi korteks adrenal untuk merangsang pengeluaran kortisol. ${ }^{8}$ Menurut penelitian Kim JW et al yang dilakukan pada tahun 2012, kurang tidur diketahui menyebabkan perubahan pada pola sekresi endokrin karena bersifat sebagai stresor. Hal ini terbukti dengan terjadinya perubahan kadar hormon testosteron dan gangguan ereksi pada pria. ${ }^{9}$

Penelitian pada hewan percobaan dalam kedaaan kurang tidur juga menyebabkan stres, akibatnya terjadinya peningkatan hormon Corticotropic Releasing Hormone ( $\mathrm{CRH})$ yang akan memicu pengeluaran kartisol yang tinggi, karena aktivitas sumbu HPA. ${ }^{10}$ Penekanan sumbu HPA juga akan meningkatkan aktivitas sistem saraf simpatis dan respon adrenal. Peningkatan sistem saraf simpatis oleh stresor akan memicu pelepasan neurotransmitter norepinefrin (NE) lokal pada ujung saraf simpatis postganglionik, sedangkan aktivitas stresor pada medulla adrenal adalah merangsang epinefrin (E) ke dalam sirkulasi sehingga akan terjadi vasokontriksi. ${ }^{11}$

Peningkatan ini dapat merangsang lepasnya Gonadotropin Releasing Hormon (GnRH) ke sistem portal menuju ke hipofisis anterior. Peningkatan $\mathrm{GnRH}$ akan merangsang lepasnya 2 hormon gonadotropin dari hipofisis anterior yaitu Follicle Stimulating Hormone (FSH) dan Luteinizing Hormone (LH). Hormon FSH dan LH berperan sebagai regulator sel Sertoli dan sel Leydig. Jika terjadi defisiensi FSH dan $\mathrm{LH}$, maka secara tidak langsung terjadi kegagalan sel Sertoli dan sel Leydig. Dalam kadar optimal sel Leydig akan memproduksi hormon testosterone, sedangkan hormon testosteron ini dipertahankan dan meningkatkan kelangsungan spermatogenesis. ${ }^{12}$

Testosteron dibentuk oleh sel Leydig yang terletak pada interstitial antara tubulus seminiferus. Produksi testosteron oleh sel Leydig dikontrol dan diregulasi oleh sel neuroendokrin. Sistem neuroendokrin ini dikenal juga sebagai pengontrol homeostasis termasuk didalamnya circardian 
rhythmicity (siklus ritme tubuh) dan siklus bangun tidur. $^{13}$

Berdasarkan uraian diatas, diasumsikan bahwa gangguan tidur akan menekan produksi kadar hormon testosteron dan spermatogenesis. Untuk membuktikan asumsi ini akan dilakukan penelitian pada tikus jantan Wistar yang mengalami gangguan tidur terhadap kadar testosteron dan aktivitas spermatogenesis.

\section{METODE}

Jenis penelitian ini adalah eksperimen dengan desain peneltian post test only control group design. yaitu rancangan yang digunakan untuk mengukur pengaruh perlakuan pada kelompok eksperimen dengan cara membandingkan perlakukan dengan kelompok kontrol. Populasi penelitian adalah tikus jantan Wistar yang berumur 2-3 bulan, dengan berat badan kira-kira 300 - 350 gr. Besar sampel dalam penelitian sebanyak 24 ekor. Untuk pemeriksaan kadar hormon testosteron dilakukan di Laboratorium Biokimia Fakultas Kedokteran Universitas Andalas, sedangkan untuk pemeliharaan dan pemeriksaan jumlah spermatozoa dilakukan di Laboratorium Fakultas Farmasi Universitas Andalas. Variabel independen adalah gangguan tidur dan variabel dependen adalah kadar hormon testosteron dan jumlah spermatozoa.

Prosedur Kerja: Tikus dikelompokan empat kelompok: 1 kelompok kontrol dan 3 kelompok perlakuan dengan perlakuan 5 hari, 10 hari dan 15 hari. Masing-masing kelompok terdiri dari 6 ekor tikus. Tikus kelompok kontrol diletakan pada kandang tanpa air dengan waktu tidur 8-9 jam. Tikus percobaan diletakan di kandang yang telah didesain dan diberi air hingga $1 \mathrm{~cm}$. Ruang percobaan dikontrol dengan siklus terang gelap. Pada awal tidur, tikus akan kehilangan tonus otot dan kemudian tikus akan jatuh ke air sehingga terbangun. Pengambilan darah di sinus orbital mata sebanyak $\pm 2-3 \mathrm{ml}$. Pengukuran kadar hormon dilakukan dengan metode RIA. Pengambilan sperma di saluran vas deferan dengan membedah tikus terlebih dahulu. Sperma di tampung di gelas arloji dan ditambah larutan $\mathrm{NaCl}$ 0,9\% sebanyak 0,5 ml dan diaduk agar homogen, kemudian diambil sebanyak 0,5 $\mathrm{ml}$ dengan pipet eritrosit dan tambahkan larutan George $0,5 \mathrm{ml}$ dan diaduk homogen. Ambil $10 \mu$ sampel dan masukan ke dalam kotak hemositometer Improved Neubauer dan hitung jumlah spermatozoa yang terlihat didalam 25 kotak bilik hitung tersebut.

Analisis Data dilakukan uji normalitas terlebih dahulu dengan uji Saphiro-Wilk. Analisis data yang digunakan adalah uji statistik parametrik One Way Anova, kemudian dilanjutkan dengan uji Multiple Comparisons (post hoc test) jenis Bonferroni.

\section{HASIL}

Variabel yang di diperiksa pada penelitian ini adalah kadar hormon testosteron dan jumlah spermatozoa. Hasil pengukuran kadar hormon testosteron dapat dilihat pada Tabel 1 dan 2.

Tabel 1. Rerata kadar hormon testosteron tikus pada kelompok kontrol dan kelompok perlaku

\begin{tabular}{lcc}
\hline \multicolumn{1}{c}{ Perlakuan } & Rerata \pm SD & p \\
\hline Kontrol & $4,96 \pm 0,50$ & 0,000 \\
Perlakuan 5 hari & $4,21 \pm 0,39$ & \\
Perlakuan 10 hari & $3,99 \pm 0,27$ & \\
Perlakuan 15 hari & $3,31 \pm 0,32$ & \\
\hline
\end{tabular}

Tabel 1 menunjukan bahwa terdapat perbedaan yang bermakna rerata kadar hormon testosteron pada kelompok kontrol dan kelompok perlakuan.

Tabel 2. Hasil uji statistik multiple comparisons pada kadar hormon testosteron tikus kelompok kontrol dengan kelompok perlakuan

\begin{tabular}{llcc}
\hline \multirow{2}{*}{ Kontrol } & Perlakuan & $\begin{array}{c}\text { Mean } \\
\text { Difference } \\
(\mathbf{I}-\mathrm{J})\end{array}$ & $\mathbf{p}$ \\
\hline \multirow{2}{*}{ Kontrol } & Perlakuan 5 hari & $0,74833^{*}$ & 0,023 \\
& Perlakuan 10 hari & $0,97333^{*}$ & 0,002 \\
& Perlakuan 15 hari & $1,65333^{*}$ & 0,000 \\
\hline
\end{tabular}

Tabel 2 menunjukan bahwa antara kelompok kontrol dan perlakuan terlihat perbedaan yang bermakna kadar hormon testosteron pada gangguan tidur 5 hari hingga 15 hari $(p<0,05)$.

Hasil pemeriksaan jumlah spermatozoa dapat dilihat pada Tabel 3 dan 4 berikut ini. 
Tabel 3. Rerata jumlah spermatozoa (juta/ml) tikus pada kelompok kontrol dan kelompok perlakuan

\begin{tabular}{lcc}
\hline \multicolumn{1}{c}{ Perlakuan } & Rerata \pm SD & P \\
\hline Kontrol & $53,50 \pm 3,72827$ & 0,000 \\
Perlakuan 5 hari & $34,33 \pm 4,54606$ & \\
Perlakuan 10 hari & $24,83 \pm 3,54495$ & \\
Perlakuan 15 hari & $21,50 \pm 1,04881$ & \\
\hline
\end{tabular}

Tabel 3 menunjukan bahwa terdapat perbedaan yang bermakna rerata jumlah spermatozoa pada kelompok kontrol dan perlakuan.

Tabel 4. Hasil uji statistik multiple comparisons pada jumlah spermatozoa tikus kelompok kontrol dengan kelompok perlakuan

\begin{tabular}{llcl}
\hline \multirow{2}{*}{ Kontrol } & Perlakuan & $\begin{array}{c}\text { Mean } \\
\text { Difference } \\
(\mathbf{I}-\mathbf{J})\end{array}$ & $\mathbf{p}$ \\
\hline \multirow{2}{*}{ Kontrol } & Perlakuan 5 hari & $19,16667^{*}$ & 0,000 \\
& Perlakuan 10 hari & $28,66667^{*}$ & 0,000 \\
& Perlakuan 15 hari & $32,00000^{*}$ & 0,000 \\
\hline
\end{tabular}

Tabel 4 menunjukan bahwa antara kelompok control dan perlakukan terlihat perbedaan yang bermakna jumlah spermatozoa pada gangguan tidur 5 hari hingga 15 hari $(p<0.05)$.

\section{PEMBAHASAN}

Berdasarkan Tabel 1 dan 2 terdapat perbedaan bermakna rerata kadar hormon testosteron antara kelompok kontrol dan perlakuan dengan nilai $p=0,000$ dan uji Multiple Comparison didapatkan bahwa antara kelompok kontrol dengan perlakuan gangguan tidur 5 hingga 15 hari telah terlihat perbedaan yang bermakna terhadap kadar hormon testosteron $(p<0,05)$.

Penurunan rerata kadar hormon testosteron pada gangguan tidur disebabkan karena adanya stres yang terjadi pada hewan perlakuan. Hal ini dibuktikan selama perlakuan gangguan tidur pada hewan coba terlihat hewan coba panik dan stres saat tidur dan jatuh kedalam air yang ada dikandang. Sehingga diduga bahwa penurunan kadar hormon testosteron disebabkan karena stres yang muncul pada tikus kelompok perlakuan. Semakin lama gangguan tidur, maka semakin besar stres yang terjadi, akibatnya akan mempengaruhi penurunan kadar hormon testosteron.
Venancio et al menyatakan bahwa terdapat pengaruh kurang tidur terhadap penurunan kadar hormon testoesteron dengan $p=0,01 \quad(p<0,05)$. Penurunan kadar testosteron karena adanya stres yang akan mempengaruhi korteks adrenal untuk merangsang pengeluaran kortisol, sehingga penurunan kadar hormon testosteron plasma selama kurang tidur secara langsung berkaitan dengan peningkatan kortisol. ${ }^{8}$

Stres yang muncul dapat mempengaruhi aksis hipotalamus-hipofisis-adrenal. Jika terjadi peningkatan stres yang berlebihan pada hipotalamus, korteks adrenal tidak mampu berespon terhadap peningkatan sekresi ACTH dengan meningkatkan pengeluaran kortisol yang berlebihan. Pengeluaran kortisol yang berlebihan akan menghambat gonadotropin, sehingga akan mempengaruhi sekresi $\mathrm{FSH}$ dan $\mathrm{LH}$ yang berdampak terganggunya spermatogenesis sehingga pembentukan kadar hormon testosteron akan terjadi penurunan. ${ }^{14}$

Stres yang berlebihan bisa menyebabkan stimulus yang buruk sehingga dapat menyebabkan gangguan pada tubuh dan sistem hormonal. Stres juga bisa memberikan dampak terhadap terhadap fisik, psikologis, intelektual, sosial dan spiritual. ${ }^{6}$

Testosteron merupakan hormon seks pria yang disekresikan oleh testis bersama beberapa hormon seks lain yang dinamakan androgen. Testosteron dibentuk oleh sel Leydig yang terletak pada interstitial antara tubulus seminiferus. Produksi testosteron oleh sel Leydig dikontrol dan diregulasi oleh sel neuroendokrin. Sistem neuroendokrin ini dikenal juga sebagai pengontrol homeostasis termasuk didalamnya circardian rhythmicity (siklus ritme tubuh) dan siklus bangun tidur. ${ }^{7,15}$

Berdasarkan Tabel 3 dan 4 terlihat perbedaan bermakna rerata jumlah spermatozoa antara kelompok kontrol dengan perlakuan dengan nilai $p=0,000$ dan uji Multiple Comparison didapatkan bahwa antara kelompok kontrol dengan perlakuan gangguan tidur 5 hari hingga 15 hari telah terlihat perbedaan yang bermakna terhadap jumlah spermatozoa $(p<0.05)$.

Penurunan jumlah spermatozoa pada penelitian ini disebabkan karena terjadinya penurunan kadar hormon testosteron yang disebabkan karena 
stres yang terjadi akibat efek gangguan tidur.

Akibat stres terjadi pengeluaran epinefrin sehingga akan meningkatkan rangsangan pada sumbu Hipotalamus-Pituitari-Adrenal, sehingga pengeluaran $\mathrm{CRH}$ yang tinggi dan merangsang $\mathrm{ACTH}$ mengeluarkan kortisol, akibatnya menekan $\mathrm{GnRH}$ sehingga menyebabkan penurunan sekresi LH dan FSH dan testosteron. Akibat dari penurunan kadar hormon testosteron juga dapat menganggu proses spermatogenesis yang berdampak terhadap pematangan spermatozoa. $^{7}$

Stres yang terjadi menimbulkan hambatan proses pada tingkat hipotalamus dan menyebabkan gangguan hormonal sehingga menyebabkan terjadinya kegagalan pada sel leydig dalam mensekresi hormon testosteron. Akibat menurunnya kadar hormon testosteron sehingga menyebabkan gangguan proses pematangan spermatozoa dalam epididimis. ${ }^{16}$

Penurunan jumlah spermatozoa juga disebabkan perbedaan rerata jumlah spermatozoa yang dihasilkan karena perbedaan bobot testis dari tikus dan mungkin juga penurunan berat dari pada testis serta perubahan bentuk dari testis sehingga terjadi perubahan pada tubulus seminiferus.

Menurut Venancio et al pada tahun 2012, bahwa kurang tidur ternyata membuat penurunan jumlah spermatozoa yang disebabkan karena terjadinya perubahan ukuran testis lebih kecil secara bermakna dengan nilai $p=0.001$, sedangkan pada bentuk histologi prostat terjadi perubahan bentuk epitel secara bermakna dengan nilai $p=0,001 \quad(p<0,05)$. Penurunan dan perubahan yang terjadi disebabkan karena stres yang muncul akibat dari kurang tidur. ${ }^{8}$

Jumlah spermatozoa yang dihasilkan sangat tergantung pada proses spermatogenesis dalam tubulus seminiferus. Bila proses spermatogenesis berlangsung normal maka akan dihasilkan jumlah spermatozoa yang normal juga. Sebaliknya jika selama proses spermatogenesis terjadi gangguan, maka mempengaruhi jumlah spermatozoa yang dihasilkan. Proses spermatogenesis dikendalikan oleh hormon testosteron, kalau kadar hormon testosteron dalam darah menurun dan berdampak terhadap penurunan jumlah spermatozoa. ${ }^{17}$

Testis merupakan suatu kelenjer ganda karena mempunyai fungsi eksokria dan fungsi endokrin. Hasil eksokrin terutama adalah sel-sel seks dan hasil endokrin adalah menghasilkan hormon testosteron. Testis dikontrol oleh dua hormon gonadotropin yang disekresi oleh hipofisis anterior yaitu $\mathrm{LH}$ dan $\mathrm{FSH} .{ }^{18,19}$

\section{KESIMPULAN}

Pada penelitian ini dapat disimpulkan bahwa terdapat pengaruh yang bermakna antara gangguan tidur terhadap kadar hormon testosteron dan jumlah spermatozoa pada tikus jantan wistar.

\section{UCAPAN TERIMA KASIH}

Terimkasih kepada staf laboratorium. Farmasi Universtas Andalas dan Biokimia Fakultas Kedokteran Universitas Andalas.

\section{DAFTAR PUSTAKA}

1. Nurani NA. 50-Juta pasangan didunia infertilitas. 2012. Tersedia dari: URL: HYPERLINK http;//www. Healk,Oke Health/red/2012/12/27/482/73 8026.

2. Depkes. Pedoman pelaksanaan kegiatan KIE kesehatan reproduksi. Jakarta: Depkes; 2008.

3. Farial EW. Kajian infertilitas pria dan usaha penanganannya. 2012. Tersedia dari: URL: HYPERLINK http://www.fakultasUNHAS.com2012 12.

4. Oentung S. Simposium kesehatan reproduksi pria. 2000.Tersedia dari: URL: HYPERLINK http://www/ pd.persi.co.id.

5. Sugianto. Infertilitas. 2008. Tersedia dari: URL: HYPERLINK http;//www.Infertilitas Com

6. Nurdin AE. Psikoneuroimunologi dasar. Edisi ke-5, Padang: EGC; 2013.

7. Sherwood, Laurellee. Human physiology: from cell to system. Alih Bahasa: Brahm, U Pandit. Jakarta: EGC; 2001.

8. Venancio DP, Andersen M, Santos FC. Sleep deprivation alters rat ventral prostate morphology leading to glandular atrophy: a microscopic study contrasted with the hormonal assays. 2012. 
9. Kim JW, Jin MH, Kim JJ, Moon DU. Influence of paradoxical sleep deprivation and sleep recovery on testosterone level in rats of different ages. Asia Journal of Andrology. 2012;(14):330-4

10. Jauch.CK, Schmid SM, Hallschmid M, Kerstin. Pituitary-Gonadal and Pituitary-Thyroid Axis Hormone Concentrations before and during a Hypoglycemic Clamp after Sleep Deprivation in Healthy Men, PLoS ONE. 2013;8(1):e54209. doi:10.1371/journal.pone.0054209.

11. Norman AW, Litwack G, Hormone academic press, Inc, San Diego New York. Boston. 1987.hlm.45069.

12. Guyton AC, Hall JE. Texbook of medical phisiology. Alih Bahasa: Irawati Setiawan. Jakarta: EGC; 2000.hlm.1284-98.

13. Guyton AC. Fisiologi kedokteran dan mekanisme penyakit edisi revisi. Alih Bahasa: Andrianto $P$.
Jakarta: EGC;1995.hlm.1265-82.

14. Laatikainen TJ. Corticotropin-releasing hormone and peptides in reproduction and stress. An Med. $1991 ; 23(5): 489-96$.

15. Hidayat N. Testosteron bebas pada alopesia androgenetik. 2005.

16. Ganong WF. Pathophysiology of diseases: an introduction to clinical medicine. Edisi ke-5. Lange; 2005.

17. Greenspan FS, Baxter JD. Endokrinologi dasar dan klinik. Alih Bahasa: Wijaya C, Maulany RF, Samsudin S. Jakarta: EGC; 2000.

18. Prendergast, Herasherzig A, Dalakin A. GnRHgonadotropin physiologi and pathology. 2002.

19. Maryunani A. Biologi reproduksi. Dalam: Kebidanan. Jakarta: CV Trans Info Media; 2010. hlm.159-82. 